\title{
Um olhar no Brasil: problemas na agenda do crescimento
}

Demian Castro*

Em 2002 as forças políticas que elegeram o presidente Lula fizeram um discurso de mudança que os eleitores acharam possível. Acreditou-se que seria possível estabelecer um novo modelo de desenvolvimento, calcado em graus maiores de soberania e orientado à redução das enormes disparidades sociais e regionais do País.

O processo de estabilização da economia atrelado à abertura comercial e financeira e, também, à oferta de ativos públicos desvalorizados, irretocável enquanto resultado, deixava, no entanto, enorme fragilidade e vulnerabilidade no balanço de pagamentos. Internamente, a dívida pública apresentava trajetória de descontrole, em patamares superiores a $60 \%$ do PIB, precariamente amortecidos pelo ajuste fiscal permanente. Depois da desvalorização do Real, a política monetária passou a ser regida pelo sistema de metas de inflação e, a fiscal, pelo sistema de metas de superávit primário, contudo, sem alterar a direção geral que vinha sendo executada pelas autoridades econômicas do País. Em linhas gerais, os desequilíbrios herdados eram combatidos com o ajuste fiscal, a busca de poupança primária, a reforma do Estado alcançando os governos sub-nacionais e, em termos gerais, com recessão ou repressão contínua ao crescimento endógeno.

$\mathrm{O}$ ardil da fuga de capitais e volta à inflação produziam, diante da iminência da vitória do PT, algum consenso entre os analistas mais sérios, no sentido de que seria necessário, no começo de governo, rigor fiscal e ortodoxia financeira para acalmar os mercados. A adesão programática, em 2002, ao sistema de metas de inflação (e suas peculiaridades) causou as primeiras baixas entre os economistas do PT. O apoio da Federação Brasileira dos Bancos (FEBRABAN) anunciava que, desde o interior do governo, um bloco de interesses predominantemente financeiros lutaria para fazer prevalecer sua posição e, em alguma medida, exerceria o papel de contrapeso ou antítese do espectro de forças políticas que levaram o PT ao poder.

O futuro mostrou que o PT permitiu sem grandes remorsos (a expulsão de militantes históricos foi uma das faces premonitórias da afirmação de uma nova política de gestão capitalista) a consolidação da política econômica conveniente às finanças globais:

\footnotetext{
* Doutor em Economia pela Universidade de Campinas (Unicamp). Professor do Departamento de Economia da Universidade Federal do Paraná. Endereço eletrônico: demian@,ufpr.br
} 
remunerou, e muito bem, o insaciável setor financeiro e, impôs um brutal constrangimento fiscal, inédito na história do País. Dois aspectos merecem destaque.

O primeiro, a política econômica executada, além de consagrar o "vôo de galinha" sufocou o campo fiscal e qualquer possibilidade de produzir resultados sociais consistentes com um ambiente de paz social duradoura. Basta dizer que a menina dos olhos da política social foi uma bolsa família ampliada, totalmente assistencialista, geradora de impactos na distribuição da renda, dados os níveis elevados de população excluída de rendimentos monetários, mas incapaz de ocasionar mudanças estruturais nas condições de vida. Não houve sequer decisão política de consertar pontes de rodovias vitais para a circulação da riqueza nas regiões Sul e Sudeste, como foi o caso da BR 116. O gasto público foi para o limbo como nenhum obcecado monetarista teria sonhado.

O segundo aspecto, talvez muito mais grave, é que essa gestão provocou simultaneamente uma desmobilização e desarticulação da base mais organizada da sociedade, parte dela, militante histórica do partido, mas, uma parte muito importante dessa base, também tinha sido ampliada com a entrada de outros segmentos sociais em crise com as políticas de ajuste neoliberais praticadas nos anos noventa. Esta desmobilização política era necessária para aliviar qualquer pressão sobre o ministério da fazenda e o Banco Central. Todo o processo de corrupção que contaminou o governo e isolou o presidente da república só veio aprofundar a desmobilização política e a abrir espaço para o surgimento da "não política”. A falta de políticas públicas consistentes ameaça hoje a sociabilidade nas metrópoles brasileiras, seja por graves problemas de infra-estrutura urbana, seja pela explosão e banalização da violência.

Quatro anos se passaram, embora a partir do terceiro ano, o governo perdeu força política e programática, entrando num jogo defensivo e muito intenso contra as denúncias e provas de corrupção. Ao mesmo tempo, a onda de denúncias e investigações antecipou o fim do governo e, prematuramente, colocaram na pauta a questão da sucessão e possível reeleição do presidente Lula. No entanto, o ciclo político não contaminou a política econômica, a qual demonstrou bastante independência para mover-se dentro dos parâmetros macroeconômicos considerados adequados pela equipe econômica e pelo presidente do Banco Central. Houve embates internos entre alguma corrente mais "desenvolvimentista" (principalmente após Palocci) e os setores dominantes ligados ao Banco Central, mas não chegaram a afetar a política monetária. No fim houve algum afrouxamento fiscal decorrente, em grande medida, da luta pela reeleição do presidente Lula, sem que, contudo, possa-se apontar a explosão de 
desequilíbrios fiscais. O debate hoje gira em torno de como recuperar a capacidade de realizar investimentos públicos mediante o corte de gastos correntes e, mais importante, no âmbito de um regime fiscal restritivo.

Observe-se que, a situação financeira externa do País, em 2006, é infinitamente melhor do que em 2002/2003, marcados por acentuada vulnerabilidade externa. O governo conseguiu corrigir os desequilíbrios externos, em parte ajudado pelo desempenho das exportações. A gestão do balanço de pagamentos certamente hoje gera menos preocupações do que quando o presidente assumiu pela primeira vez em 2003. As duas principais forças políticas que disputaram o segundo turno centraram boa parte do discurso na necessidade de retomar o crescimento sustentado, agora que a "casa está em ordem".

Ao final de 2006, confirma-se o crescimento pífio da economia com perspectivas sombrias para 2007. E, pelas notícias na imprensa sobre os debates para a retomada, é sintomático observar que não será fácil para o presidente e sua equipe econômica promover o crescimento sem quebrar alguns ovos, mudando alguns dos parâmetros que conduziram a política econômica até hoje. Este é o grande problema: será que é possível compatibilizar a boa gestão do balanço de pagamentos com uma política econômica mais “endógena” capaz de dinamizar a demanda e o mercado interno? Uma política econômica capaz de produzir crescimento sustentado e vigoroso será compatível com os gigantescos lucros financeiros dos últimos anos?

Junto aos problemas correlacionados à mudança da política econômica, há outros igualmente preocupantes que, também, influenciam a capacidade de alimentar e conduzir o crescimento da Nação. Eles dizem respeito à capacidade social de definir projetos, de produzir progresso técnico e revolucionar o ciclo econômico. Em que pesem os avanços democráticos, de algumas políticas sociais e da estabilidade econômica, não são comuns, no Brasil, exemplos de "soluções coletivas" que demandem cooperação e coordenação entre atores públicos e privados. Prevalecem as "soluções atomizadas e defensivas". As chamadas reformas microeconômicas que, para muitos, são essenciais para a retomada do crescimento (mas que não abrangem a questão do progresso técnico), requerem forte capacidade de iniciativa e mobilização política do governo federal que, até o presente momento, não tem sido demonstrada. Uma política industrial vigorosa e ativa requer, além de sólida capacidade de financiamento e taxas de juros adequadas, envolvimento permanente entre atores e instituições profundamente heterogêneas, práticas incomuns no Brasil individualista e competitivo de hoje. 
Mais do que as soluções técnicas, parece que o momento atual demanda entender que o crescimento econômico e seus caminhos dependem de decisões políticas articuladas e sustentadas desde o interior do Estado. 